\title{
KOMUNIKASI POLITIK DARING: STUDI PERBINCANGAN POLITIK DI TWITTER PADA MASA KAMPANYE PEMILIHAN PRESIDEN INDONESIA 2019
}

\section{ONLINE POLITICAL COMMUNICATION: AN OVERTIME ANALYSIS OF ONLINE POLITICAL TALK ON TWITTER DURING THE 2019 INDONESIAN PRESIDENTIAL ELECTION CAMPAIGN}

\author{
Wahyu Nova Riski; Yohanes Thianika Budiarsa² \\ ${ }^{1}$ University of Melbourne \\ ${ }^{2}$ Universitas Katolik Soegijapranata \\ email: ${ }^{1}$ wahyunovariski@gmail.com; ${ }^{2}$ thian@unika.ac.id
}

\begin{abstract}
This research aims to demonstrate political polarization online. Computerised social network analysis was employed to collect and analysis social media data extracted from Twitter. Two keywords, including \#2019GantiPresiden (in English: \#2019ChangePresident) and \#2019TetapJokowi (in English: \#2019StillJokowi) were used in collecting data from Twitter. This research finds that political polarization online seems to exist based on the topic and figure of political debate. Our data demonstrates that online political talk surrounding the \#2019GantiPresiden keyword is consistently showing political polarization while those of \#2019TetapJokowi is consistently fragmented.
\end{abstract}

Keywords: political talk, election, campaign, Twitter, Indonesia

\section{Abstrak}

Studi ini bertujuan untuk mempelajari bagaimana polarisasi politik terjadi secara daring. Pengumpulan dan analisis data Twitter dalam studi ini dilakukan melalui social network analysis berbasis komputer. Dua kata kunci yang dipilih untuk pengumpulan data adalah \#2019GantiPresiden dan \#2019TetapJokowi. Hasil analisis data menemukan adanya polarisasi politik secara daring berdasarkan topik dan figur politik yang terlibat. Studi ini menyimpulkan bahwa perbincangan politik secara daring yang melibatkan kata kunci \#2019GantiPresiden secara konsisten menunjukkan polarisasi politik. Di sisi lain, perbincangan dengan kata kunci \#2019TetapJokowi secara konsisten terfragmentasi.

Kata Kunci: komunikasi politik, pilpres, kampanye, Twitter, Indonesia

\section{PENDAHULUAN}

Twitter merupakan salah satu platform digital yang semakin berperan dalam proses komunikasi politik. Banyak ahli berpendapat bahwa media sosial mulai digunakan dalam kampanye pemilihan umum (pemilu) dan menjadi platform diskusi politik sejak Pemilu 2008 di Amerika Serikat (Skovsgaard \& van Dalen, 2016). Ada beberapa alasan mengapa media sosial semakin memegang peranan penting dalam komunikasi politik. Pertama adalah faktor kemudahan yang ditawarkan oleh media sosial. Para pengguna media sosial hanya perlu mengetik pesan singkat dan mengunggah pesan tersebut pada platform mereka untuk terlibat dalam proses politik. Pada saat yang sama mereka juga dapat mengomentari atau merespon status yang diunggah oleh para pengguna yang lain (Himelboim et al., 2013). Kedua, media sosial juga memfasilitasi terjadinya interaksi yang antara politikus dan para pendukung mereka (Lilleker et al., 2016). 
Ketiga, peran media sosial menjadi semakin signifikan dalam proses komunikasi politik karena ia memungkinkan para pengguna menyatakan pandangan politik pribadi mereka secara praktis (Sunstein, 2009).

Penelitian maupun literatur yang mengkaji penggunaan platform media sosial dalam komunikasi politik pun semakin banyak ditemukan, misalnya tentang analisis partisipasi publik dalam diskusi politik (Bruns \& Burgess, 2011; Himelboim et al., 2013) maupun penggunaan media sosial oleh politikus ketika berkomunikasi dengan para pendukung mereka (Lilleker et al., 2016; Skovsgaard \& van Dalen, 2016). Peran media sosial dalam proses komunikasi politik juga ditegaskan oleh Boynton et al. (2014: 14).

There is much more communication interaction rather than simply broadcast in the political use of Twitter. Hashtags are an invitation to communication [... .,] retweeting is an indication of reading in the domain [... .,] URLs bring communication external to Twitter into the domain.

Tidak dapat dimungkiri bahwa studi-studi tersebut layak untuk dikritik, sebab kebanyakan berfokus di Amerika Serikat atau negara-negara Barat lainnya. Namun demikian, salah satu kekhasan dari studi-studi tersebut ialah para peneliti menganalisis dampak penggunaan media sosial pada aspek komunikasi dan politik serta pengaruhnya terhadap wacana politik yang sedang berkembang (Bennet, 2003; Tumasjan et al., 2010; Stieglitz et al., 2012).

Lalu bagaimana sejumlah studi dan literer tersebut mengkaji penggunaan media sosial untuk tujuan-tujuan politik, baik yang dilakukan oleh para politikus pada khususnya maupun warganet pada umumnya? Pertama-tama, diperlukan tinjauan pustaka untuk memperoleh gambaran sejauh mana penelitian yang sudah dilakukan untuk membahas proses komunikasi politik secara daring. Tinjauan pustaka diawali dengan mengulas karakteristik Twitter sebagai salah satu media sosial yang populer dalam proses komunikasi politik. Dilanjutkan dengan mencermati berbagai studi komunikasi politik yang menggunakan metode social network analysis (SNA). Penerapan metode SNA dalam suatu penelitian media sosial dilakukan untuk memahami sejauh mana struktur jejaring sosial dari suatu diskusi politik terpolarisasi.

Sebagaimana platform media sosial yang lain, Twitter juga memfasilitasi penggunanya untuk berbagi informasi. Para pengguna Twitter dapat menyampaikan pesan melalui empat fitur seperti tweet, retweet, reply, dan mention. Tweet atau kicauan adalah salah satu jenis pesan yang dapat dikirimkan oleh pengguna Twitter dan dibatasi maksimal 280 karakter per pesan. Retweet adalah salah satu jenis penyampaian pesan di mana pengguna meneruskan pesan (tweet) pengguna lain secara langsung, tanpa mengubah konten tweet tersebut. Reply adalah aktivitas yang dilakukan oleh pengguna Twitter untuk mengomentari pesan yang disampaikan oleh pengguna lain. Sedangkan mention merupakan aktivitas yang dilakukan oleh pengguna ketika mereka bermaksud menyebutkan pengguna Twitter yang lain dalam pesan yang mereka kirim. Melalui fitur-fitur tersebut para pengguna Twitter dapat membagikan, memberikan komentar, mendiskusikan, bahkan memperdebatkan berbagai informasi mulai dari perasaan personal hingga gosip, atau membahas topik-topik tertentu baik yang berkaitan dengan pengetahuan umum maupun ilmu pengetahuan yang spesifik. Oleh karena itu, diskusi politik hanyalah sebagian kecil dari apa yang ada di Twitter. 
In this way, political dialogue becomes embedded in other contexts in much the same way as faceto-face political discussion might take place in the context of an office, a vehicle, a sporting event, a meal, a pub, or through other public activities (Himelboim et al., 2013, p. 158).

Twitter juga mempunyai fitur lain yang penting yaitu hashtag (\#) atau tagar. Sebuah forum diskusi atau forum tertentu dapat dibentuk melalui penggunaan tagar. Misalnya, pengguna Twitter yang menyukai olahraga dapat menggunakan tagar khusus yang menghubungkan pesan mereka dengan para pengguna lain yang juga memiliki minat yang sama. Dengan cara ini, sebuah forum yang secara implisit terkait dengan olahraga dapat dibentuk. Dalam beberapa kasus, diskusi yang terkait dengan topik politik pun terjadi di berbagai forum non-politik. Sebagaimana dinyatakan oleh Wojcieszak \& Mutz (2009) berdasarkan penelitian mereka di Amerika Serikat, persentase diskusi politik yang terjadi dalam berbagai forum non-politik ternyata tinggi. Bahkan diskusinya pun bersifat interaktif karena mereka yang terlibat saling menimpali satu sama lain dan tidak terpolarisasi secara politik. Dapat dikatakan bahwa forum politik menjadi tempat bagi munculnya debat politik yang hidup dan bernalar.

Meskipun diskusi politik dapat dilakukan dalam forum apa pun, tidak ada jaminan bahwa pemikiran-pemikiran yang heterogen tersebut akan menjangkau setiap pengguna Twitter. Para pengguna Twitter cenderung membangun suatu jaringan yang terdiri atas para pengguna yang memiliki pandangan atau pendapat yang sama. Hal ini dapat terjadi melalui artikulasi dengan siapa saja si pengguna terhubung, misalnya dilihat dari siapa yang ia ikuti (following), apa saja tweet yang dikomentari (replying), atau siapa saja pengguna yang ia sebut (mentioning) (Himelboim et al., 2013). Dengan mengaplikasikan SNA, peneliti dapat memahami struktur dan sifat diskusi politik di Twitter secara lebih baik (Smith et al., 2014). Namun, metode tersebut rupanya masih belum banyak diadopsi dalam penelitian-penelitian komunikasi sebagaimana dinyatakan oleh Wright et al. (2016: 79), "While many researchers have made compelling case for the importance of everyday political talk, the problem, as Mansbridge noted, is that such talk is rarely analysed."

Fokus SNA adalah mencermati hubungan antar-individu, seperti dikatakan oleh Kadry \& Al-Taie (2014: 13).

Social network analysis (SNA) displays social relationships as consisting of nodes (individuals or organizations) and ties (which are also called links or edges). These nodes represent actors within the $\mathrm{SN}$, and ties represent the relationships between them.

Dengan demikian, SNA lebih memberi perhatian pada ikatan yang terjalin antar-individu dan alih-alih meneliti individu itu sendiri. Karakteristik inilah yang menjadikan SNA sebagai pendekatan penelitian yang unik dan berbeda dari pendekatan lain seperti wawancara dan survei yang cenderung berfokus pada individu. Selain itu, SNA terdiri atas beberapa pengukuran yang berbeda. Salah satu tujuan penting dari pengaplikasian SNA adalah menguji peran individu dan hubungannya dengan individu lain dalam jaringan. Dengan melakukan ini, individu-individu yang memiliki peran penting dalam jaringan dapat teridentifikasi. Lebih dari itu, melalui SNA, peneliti juga dapat mencermati struktur global jaringan untuk mengidentifikasi pola dan sifat hubungan antar-individu dalam jaringan. Sebagai hasilnya kita dapat menyimpulkan apakah sebuah jaringan terpolarisasi atau tidak. 
Banyak studi telah meneliti struktur jaringan sosial dari diskusi politik di Twitter. Para peneliti menemukan bahwa perbincangan atau diskusi politik di Twitter cenderung terpolarisasi, seperti yang Sunstein (2009) gambarkan sebagai Daily Me tercermin dalam frasa 'birds of a feather flock together' (lihat Mutz, 2006; Himelboim et al., 2013; Smith et al., 2014). Beranjak dari hal tersebut, pengguna Twitter lebih cenderung terlibat dalam pembicaraan politik dengan orang-orang yang memiliki pandangan politik serupa ketimbang dengan khalayak umum yang mungkin memiliki preferensi politik yang berbeda. Hal itu senada dengan apa yang dikemukakan oleh Himelboim et al. (2013: 154), “... Twitter users are unlikely to be exposed to cross-ideological content from clusters of users they followed, as these were usually politically homogeneous". Polarisasi struktur jaringan dari diskusi politik daring juga ditemukan dalam studi SNA yang dilakukan oleh Bruns \& Burgess (2011). Mereka menemukan bahwa para pengguna Twitter di Australia lintas profesi cenderung terpolarisasi selama masa pemilihan umum 2010 (Bruns \& Burgess, 2011). Di Asia, polarisasi politik lewat daring juga ditemukan di Korea Selatan (Lee \& Hahn, 2018). Hal ini menunjukkan polarisasi politik yang khususnya dipicu oleh diskusi politik secara daring muncul sebagai tantangan bagi demokrasi di berbagai negara (Beaufort, 2018).

Oleh karena studi atau literer dalam kajian yang sama dengan konteks di negara-negara Asia misalnya, belum banyak ditemukan. Oleh karena itu khasanah pengetahuan tentang jejaring sosial yang mengkaji diskusi politik daring di negara-negara berkembang, khususnya yang berada di kawasan Asia Tenggara, sangat perlu ditingkatkan. Penerapan SNA terhadap diskusi politik dalam konteks negara berkembang yang demokratis dapat menawarkan pemahaman yang lebih baik mengenai proses komunikasi melalui diskusi politik secara daring yang terjadi di negara-negara tersebut.

Berdasarkan hal di atas, pertanyaan umum yang diajukan dalam penelitian ini adalah:

RQ1: Bagaimana struktur jejaring sosial dari diskusi politik daring dalam masa pemilihan presiden 2019 di Indonesia dan sejauh mana polarisasi politik itu terjadi di Twitter?

Mengingat pentingnya struktur jaringan (Smith et al., 2014), individu tertentu dapat memiliki peran dan bentuk partisipasi yang berbeda dalam jaringan. Beberapa dari mereka mungkin memainkan peran lebih penting dan memiliki lebih banyak koneksi daripada individu yang lain. Memerhatikan aspek tersebut, pertanyaan umum lain yang juga diajukan dalam penelitian ini adalah:

RQ2: Berdasarkan peta jejaring sosial, siapa tokoh kunci yang terlibat dalam diskusi politik daring di Twitter?

Dapat disimpulkan bahwa berbagai literatur telah menunjukkan peran penting media sosial seperti Twitter dalam proses komunikasi politik. Polarisasi politik dan homofili cenderung menjadi karakteristik penting dari diskusi politik daring. Persoalannya sebagian besar literatur masih berfokus pada negara-negara barat. Diskusi politik daring yang terjadi di negara-negara timur masih belum banyak diteliti. Mengingat hal itu, studi ini berupaya menganalisis diskusi politik daring di Indonesia berdasarkan pertanyaan penelitian di atas. Pada bagian selanjutnya kami akan menjelaskan metodologi yang digunakan untuk menjawab pertanyaan penelitian tersebut. 


\section{METODOLOGI PENELITIAN}

Studi ini menggunakan social network analysis (SNA) untuk mengidentifikasi struktur jaringan dan aktor-aktor utama yang berpartisipasi dalam diskusi politik secara daring di Twitter dengan kata kunci tertentu. Sebelum menjelaskan bagaimana metode ini digunakan untuk menjawab pertanyaan penelitian, pada bagian ini kami akan menjelaskan data yang digunakan dan bagaimana data tersebut dikumpulkan.

Data

Sepanjang masa pemilihan umum legislatif (pileg) dan pemilihan umum presiden (pilpres) di Indonesia tahun 2019, debat politik berlangsung tidak hanya di dunia nyata (offline) tetapi juga di ranah daring seperti Twitter. Sifat keterbukaan akses Twitter memungkinkan debat dapat diikuti dengan mudah. Dua tagar terkait pemilu seperti \#2019TetapJokowi dan \#2019GantiPresiden menjadi populer di kalangan masyarakat. Tagar \#2019TetapJokowi banyak digunakan oleh para pendukung kandidat presiden petahana, Joko Widodo. Sementara tagar \#2019GantiPresiden digunakan oleh para pendukung kandidat oposisi yang mengusung Prabowo Subianto. Meskipun tidak mewakili keseluruhan debat politik mengenai pemilu yang terjadi di Twitter, setidaknya beberapa topik penting seputar pemilu terungkap dalam dua tagar tersebut.

Pengumpulan data media sosial berdasarkan kata kunci \#2019TetapJokowi dan \#2019GantiPresiden dilakukan dengan menggunakan aplikasi NodeXL, yang juga memungkinkan analisis dan visualisasi jaringan sosial secara otomatis. Dengan menggunakan NodeXL, setiap hari dapat dikoleksi hingga 8.000 pesan Twitter terbaru dari masing-masing tagar. Untuk menyiasati ketentuan application programming interface (API) Twitter yang membatasi akses pengumpulan data Twitter, pengumpulan data dilakukan secara harian sehingga seluruh pesan Twitter yang terkait dengan kata kunci dapat terjaring. Jangka waktu pengumpulan data ditentukan selama 30 hari dimulai 17 Maret dan berakhir pada 15 April 2019. Untuk memastikan konsistensi pengumpulan data, tidak ada variasi kata kunci yang digunakan selama jangka waktu pengumpulan data.

Tabel 1. Pesan Twitter dari Setiap Kata Kunci Berdasarkan Jenisnya

\begin{tabular}{cccrrr}
\hline Keyword & \multicolumn{1}{c}{$\begin{array}{l}\text { Original } \\
\text { Tweets }\end{array}$} & Retweet & Replies & Mention & $\begin{array}{c}\text { Total } \\
\text { Messages }\end{array}$ \\
\hline \#2019TetapJokowi & 98.917 & 3.483 & 5.378 & 10.261 & 118039 \\
\hline \#2019GantiPresiden & 24.219 & 79.106 & 44.985 & 129.851 & 278161 \\
\hline Total & 123.136 & 82.589 & 50.363 & 140.112 & 396.200 \\
\hline \multicolumn{7}{c}{ Sumber: olahan data peneliti }
\end{tabular}

Tabel 1 di atas menunjukkan jumlah data Twitter dari setiap kata kunci. Dalam kurun waktu 30 hari terkumpul 396.200 pesan Twitter yang terdiri atas 118.039 cuitan menggunakan tagar \#2019TetapJokowi dan 278.161 pesan Twitter mengandung kata kunci \#2019GantiPresiden. Dari pengumpulan data harian diketahui sebanyak 123.136 tweet, 82.589 retweet, 50.363 reply, dan 140.112 mention dihasilkan oleh para pengguna Twitter dengan 
menyertakan tagar \#2019TetapJokowi dan \#2019GantiPresiden. Data tersebut kemudian diteliti lebih lanjut dengan metode SNA.

\section{Analisis jaringan}

Data yang dikumpulkan dari tiap kata kunci diurutkan sesuai tanggal untuk memastikan agar data harian hanya berisi tweet yang dipublikasikan oleh pengguna Twitter pada hari yang sama. Karena data yang diambil terdiri atas beberapa jenis pesan yaitu tweet, reply, mention, dan share, NodeXL digunakan untuk mengurutkan dan menghitung data berdasarkan jenis pesan tersebut. Untuk melakukan SNA, NodeXL juga digunakan untuk mengidentifikasi klaster utama dari masing-masing tagar dengan menerapkan algoritma Caluset Newman Moore yang tersedia di aplikasi NodeXL. Algoritma ini dapat digunakan untuk mengelompokkan pengguna Twitter yang dianalisis (dalam kumpulan data) ke dalam klaster yang berbeda berdasarkan pola keterhubungan mereka terhadap pengguna lain (lihat Wakita dan Tsurumi, 2007). Sementara itu identifikasi jaringan pengguna dilakukan dengan mengadopsi konsep jaringan sosial yang diperkenalkan oleh Smith (2018) yang meliputi polarized crowd, tight crowd, brand cluster, community cluster (bazaar), broadcast network, dan support network. Gambar 1 di bawah ini menampilkan visualisasi jenis jejaring sosial di media sosial.

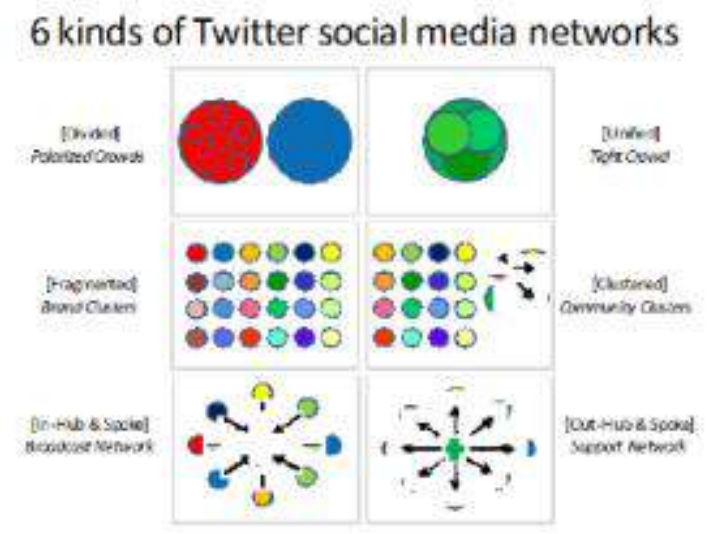

Gambar 1. Jenis Jaringan Sosial di Media Sosial Sumber: olahan data peneliti

Setiap jenis jaringan memiliki karakteristik yang berbeda. Polarized crowd adalah jaringan yang terdiri atas dua atau lebih kelompok besar dan padat. Keterhubungan antarkelompok yang terbentuk dalam polarized crowd cenderung terbatas sehingga antarkelompok pengguna tampak saling mengabaikan. Selain itu, polarized crowd terbentuk karena intensitas percakapan dan debat terpolarisasi pada topik yang sama dan pandangan politik yang serupa. Hal ini sangat berbeda dengan tight crowd yang terbentuk karena adanya keterhubungan antarpengguna dalam jaringan karena percakapan dan diskusi. Hampir seluruh pengguna yang tergabung di dalam jaringan ini saling terhubung sehingga jaringan pengguna tidak terpolarisasi.

Sementara itu, brand cluster umumnya terpolarisasi dan terdiri atas kelompokkelompok kecil karena tingkat fragmentasi yang tinggi antarpengguna dalam jaringan. Berbeda 
dengan polarized crowd dan tight crowd, pengguna dalam jaringan brand cluster cenderung tidak memiliki koneksi dengan pengguna lain dalam jaringan meskipun mereka memperbincangkan topik yang sama. Oleh karena itu, peta jaringan brand cluster mayoritas terdiri atas titik-titik (nodes) yang berdiri sendiri yang dalam teori jaringan disebut 'isolates' (Smith, 2018). Dalam SNA, titik (nodes) mewakili setiap individu dalam jaringan atau dalam penelitian ini mewakili pengguna Twitter. Sedangkan community cluster terpolarisasi oleh keberadaan sejumlah kelompok kecil dan biasanya menyerupai bazaar yang membahas topik populer tertentu. Jenis jaringan ini dapat dikatakan sebagai kombinasi polarized crowd dan brand cluster. Dalam hal ini, community cluster memiliki lebih sedikit 'isolates' daripada brand cluster. Sementara, jika dibandingkan dengan polarized crowd, kelompok yang terbentuk pada community cluster lebih kecil tetapi berjumlah lebih banyak. Diskusi yang terbentuk dalam kelompok kecil menciptakan jaringan yang padat antar-pengguna dalam community cluster.

Jenis jaringan berikutnya yaitu broadcast network yang menyerupai hubungan antara media tradisional dengan penggunanya. Alih-alih berinteraksi dengan pengguna lain dalam jaringan, pengguna dalam broadcast network cenderung hanya terhubung ke sumber siaran atau informasi. Dalam broadcast network, aliran informasi menjadi karakteristik utama di mana sumber-sumber informasi cenderung lebih sedikit dibanding pengguna mereka. Berbeda dari broadcast network, dalam beberapa kasus hanya ada satu atau dua pengguna yang merupakan bagian support network yang membagikan informasi kepada sejumlah khalayak (Smith et al., 2014; Smith, 2018).

Analisis identifikasi tokoh kunci dalam jaringan dilakukan dengan memperhatikan degree centrality (sentralitas derajat) yang merupakan ukuran popularitas pengguna Twitter di dalam jaringan sosialnya dengan menggunakan aplikasi NodeXL. Menurut Hansen et al. (2012), sentralitas derajat terdiri dari betweenness centrality, closeness centrality, dan eigenvector centrality. Studi ini hanya menggunakan betweennes centrality yang merupakan cara untuk mengukur sentralitas berdasarkan jalur terpendek (koneksi antarpengguna).

Betweenness centrality dihitung berdasarkan jumlah koneksi yang dimiliki pengguna dalam jaringan sosialnya. Semakin tinggi jumlah koneksi yang dimiliki pengguna, angka sentralitas yang muncul pun semakin besar. Oleh karena itu dalam penelitian ini pengguna dengan angka sentralitas paling besar dianggap sebagai tokoh kunci dalam jaringan. Selain untuk mengidentifikasi tokoh kunci, NodeXL juga digunakan untuk mengurutkan sepuluh pengguna teratas dari kedua tagar. Pemeringkatan angka sentralitas dilakukan dalam jangka waktu 30 hari. Selanjutnya, untuk menentukan latar belakang sosial tokoh kunci, pemeriksaan awal terhadap profil akun Twitter dilakukan secara manual.

\section{HASIL DAN PEMBAHASAN}

Sebagaimana telah dibahas pada bagian metode, studi ini dilakukan dengan menggunakan social network analysis (SNA) sebagai pisau analisis untuk mengkaji diskusi politik di Twitter sehingga pola jejaring sosial yang terbentuk dalam diskusi politik daring itu dapat diidentifikasi.

RQ1: Bagaimana struktur jejaring sosial dari diskusi politik daring dalam masa pemilihan presiden 2019 di Indonesia dan sejauh mana polarisasi politik itu terjadi di Twitter? 
Untuk menjawab pertanyaan penelitian pertama, pesan Twitter yang diambil dari kedua kata kunci diproses menggunakan aplikasi NodeXL dan kemudian dianalisis dengan metode SNA. Dari pengumpulan data harian yang dilakukan selama 30 hari, diperoleh 60 peta jejaring sosial. Enam peta jejaring sosial yang merupakan bagian dari 60 peta jejaring sosial tersebut ditampilkan pada Gambar 2. Menariknya, berdasarkan social network analysis (SNA) ditemukan bahwa jenis jaringan dari kedua tagar tersebut berbeda meskipun keduanya berkaitan dengan peristiwa politik yang sama yaitu Pipres Indonesia 2019. Social network analysis (SNA) dari kumpulan data dengan kata kunci \#2019GantiPresiden menunjukkan bahwa jaringan pengguna di dalamnya secara konsisten terpolarisasi.

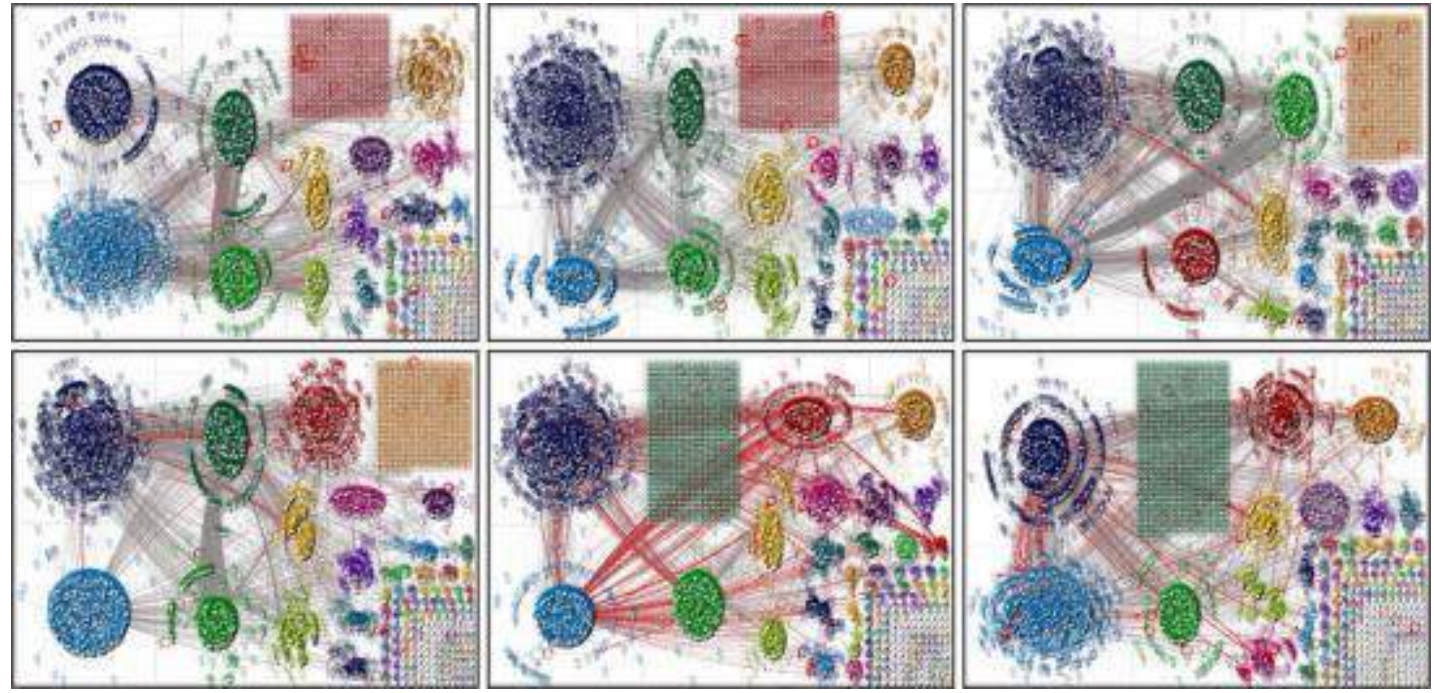

Gambar 2. Visualisasi peta jaringan pesan Twitter dengan kata kunci \#2019GantiPresiden

Gambar 2 di atas menampilkan 6 dari 30 peta jejaring sosial dari pesan Twitter dengan kata kunci \#2019GantiPresiden. Pada sisi atas dari kiri ke kanan adalah peta jaringan dari data yang diambil pada 21, 22, dan 24 Maret 2019. Pada sisi bawah dari kiri ke kanan ditampilkan peta jaringan dari kumpulan data 31 Maret, 12 April, dan 15 April 2019. Keenam peta jaringan tersebut menunjukkan bahwa pengguna Twitter yang terlibat diskusi politik dengan tagar \#2019GantiPresiden cenderung membentuk beberapa kelompok besar dan padat. Terlihat pula bahwa keterhubungan antar-kelompok yang terbentuk jauh lebih sedikit dibanding keterhubungan antarpengguna di dalam kelompok. Keterhubungan antarpengguna dilihat dari garis (line) yang terlihat pada peta jaringan. Hal ini dikonfirmasi oleh jumlah line yang menghubungkan satu kelompok dengan yang lainnya. Line yang menghubungkan antarkelompok tidak sepadat line yang menghubungkan pengguna di dalam kelompok. Penelitian lebih lanjut terhadap peta jejaring sosial ini menunjukkan bahwa koneksi antarpengguna cenderung terjadi karena pengguna mendiskusikan topik tertentu yang cenderung berbeda antarkelompok. Misalnya, ketika kelompok pertama membahas kampanye Prabowo Subianto di Solo, kelompok yang lain membahas kampanye calon presiden ini di Sumatera Selatan, akibatnya para pengguna Twitter yang membahas kampanye di Solo membentuk suatu kelompok jaringan sosial yang padat, begitu pula dengan pengguna yang membahas topik lainnya. 

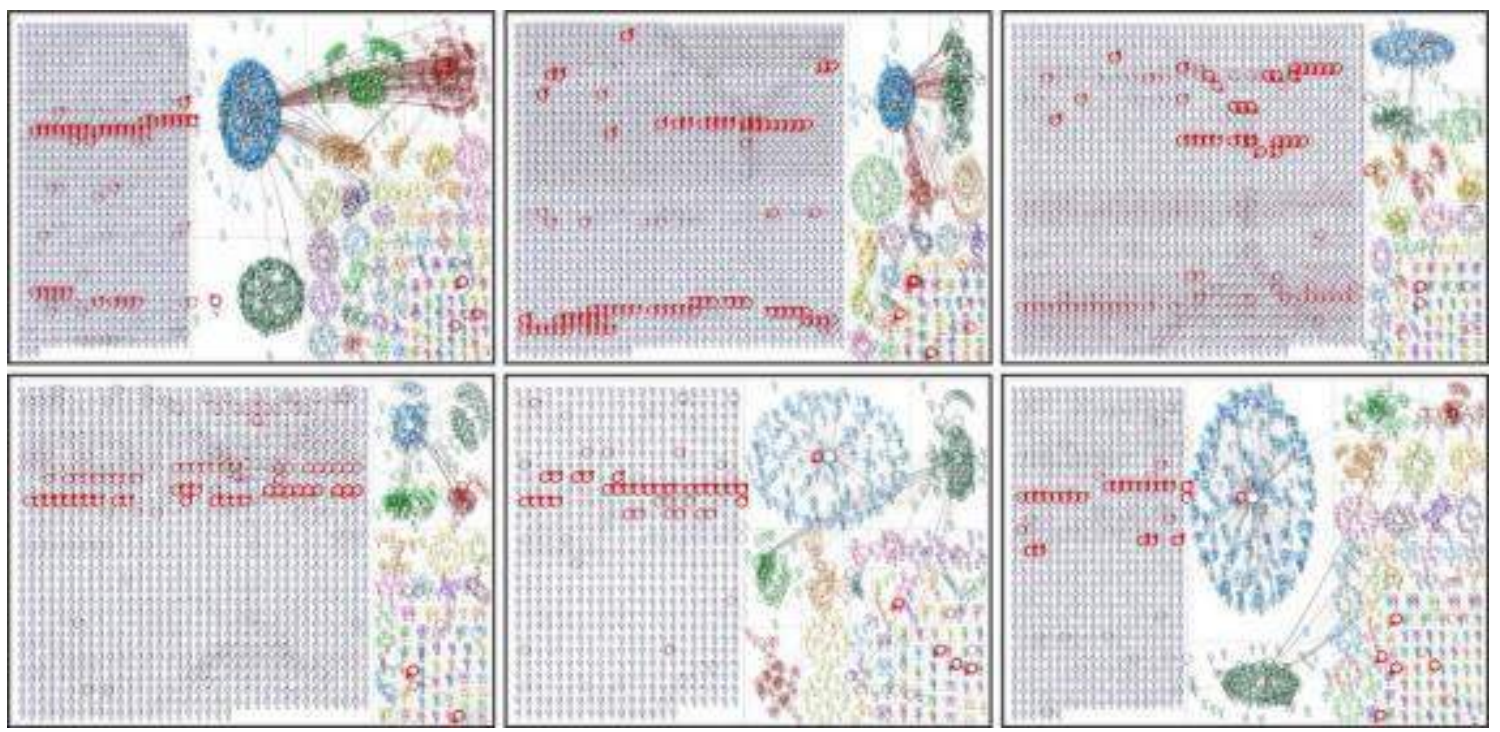

Gambar 3. Visualisasi peta jaringan pesan Twitter dengan kata kunci \#2019TetapJokowi Sumber: olahan data peneliti

Sementara itu jejaring sosial dari kumpulan pengguna Twitter yang menggunakan tagar \#2019TetapJokowi nampak terfragmentasi sebagaimana tampak pada Gambar 3 di atas. Gambar 3 adalah visualisasi dari 6 (enam) peta jejaring sosial dari diskusi politik \#2019TetapJokowi. Pada sisi atas dari kiri ke kanan ditampilkan peta jaringan dari kumpulan data 20, 22, 30 Maret 2019. Sementara di sisi bawah dari kiri ke kanan tampak peta jaringan dari data yang dikumpulkan pada 10, 12, dan 14 April 2019.

Gambar 3 juga menunjukkan bahwa sebagian besar peserta diskusi politik yang menggunakan tagar \#2019TetapJokowi cenderung mandiri. Dalam arti sebagian besar pengguna terisolasi. Mereka tidak memiliki koneksi ke pengguna lain. Sementara itu, pengguna lain dalam jaringan saling terhubung secara terbatas. Berdasarkan apa yang tampak pada Gambar 2 dan Gambar 3, jaringan yang terbentuk dari penggunaan tagar \#2019TetapJokowi secara signifikan berbeda dengan jaringan \#2019GantiPresiden. Karakteristik jaringan sosial yang terbentuk dari pengguna tagar \#2019TetapJokowi ini sesuai dengan apa yang disebut oleh Smith (2018) sebagai brand cluster dimana 'isolates', atau titik-titik yang tidak memiliki keterhubungan antara satu dengan yang lainnya, eksis. 


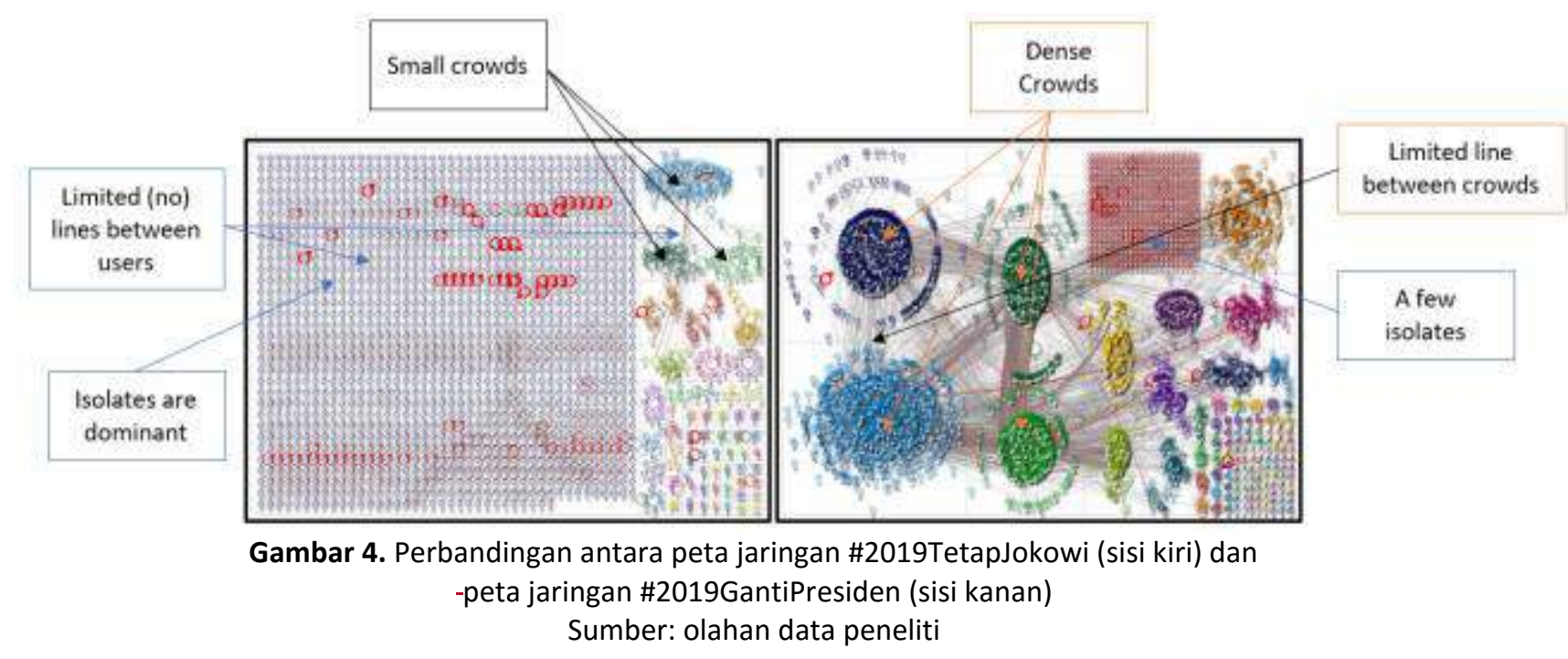

Gambar 4 di atas menyajikan perbandingan peta jaringan dari kedua kata kunci. Jaringan dengan kata kunci \#2019TetapJokowi memiliki sedikit line yang mengindikasikan koneksi antarpengguna. Sementara jaringan \#2019GantiPresiden terdiri dari beberapa kelompok yang memiliki koneksi padat antarpengguna di_dalam kelompok mereka.

Gambar 4 juga menunjukkan struktur yang berbeda antarjaringan sosial. Peta jaringan di sebelah kiri menunjukkan bahwa sekitar $80 \%$ pengguna dalam jaringan merupakan 'isolates' yang belum pernah berinteraksi satu sama lain. Sementara itu, peta jaringan di sebelah kanan secara nyata menunjukkan bahwa sebagian besar pengguna dalam jaringan berinteraksi satu sama lain. Interaksi ini dapat dilihat dari pembentukan kelompok padat dan line sebagai indikasi hubungan antar pengguna. Pada saat yang sama peta jaringan ini menunjukkan 'isolates' dalam jumlah yang sangat kecil terdapat dalam jaringan.

Singkatnya, melalui social network analysis (SNA) ditemukan bahwa dua tagar Pemilu memiliki struktur jaringan yang sangat berbeda walaupun faktanya terkait dengan topik yang sama yaitu Pilpres di Indonesia. Diskusi politik dengan menggunakan tagar \#2019GantiPresiden membentuk struktur jaringan yang disebut sebagai polarized crowd. Sementara para pengguna yang terlibat dalam diskusi politik dengan tagar \#2019TetapJokowi terfragmentasi. Ini menunjukkan bahwa kerumunan, dan sifat interaksi di dalamnya berbeda.

RQ2: Berdasarkan peta jejaring sosial, siapa tokoh kunci yang terlibat dalam diskusi politik daring di Twitter?

Sebagaimana telah dikemukakan sebelumnya, aplikasi NodeXL digunakan untuk menganalisis para tokoh kunci dalam diskusi politik berdasarkan data betweenness centrality yang diekstrak menggunakan NodeXL. Untuk mengeksplorasi lebih jauh latar belakang sosial dari para tokoh utama tersebut, dilakukan penelusuran profil Twitter mereka secara manual. Hasil penelusuran profil dikelompokkan ke dalam tiga kategori yaitu (1) politikus, jika pengguna teridentifikasi sebagai figur yang memiliki afiliasi dengan partai politik atau melakukan aktivitas politik tertentu; (2) jurnalis, jika pengguna teridentifikasi sebagai bagian dari tim editorial media sebagaimana terungkap dalam profil Twitter mereka; dan (3) warganet, jika pengguna tidak teridentifikasi sebagai politikus maupun jurnalis. Berdasarkan kategorisasi tersebut, ditemukan 
bahwa profil para pengguna Twitter yang berpartisipasi dalam diskusi politik daring bersifat heterogen. Tabel 2 di bawah ini menunjukkan 10 (sepuluh) pengguna teratas yang diurutkan berdasarkan nilai betwennes centrality dari kumpulan data pengguna tagar \#2019GantiPresiden.

Tabel 2. Top 10 Tokoh Kunci dalam Jaringan \#2019GantiPresiden

\begin{tabular}{llll}
\hline No & Nama Akun & Sentralitas Perantara & Kategori \\
\hline 1 & Prabowo & 10350248.319 & Politikus \\
\hline 2 & msapunya & 8851194.287 & Warganet \\
\hline 3 & Sandiuno & 4378079.665 & Politikus \\
\hline 4 & mardanialisera & 3998469.916 & Politikus \\
\hline 5 & nusanewsid & 3429838.920 & Jurnalis \\
\hline 6 & jackvardan & 3424015.136 & Warganet \\
\hline 7 & Cakkhum & 3269182.496 & Politikus \\
\hline 9 & sayyid_uf & 2823909.743 & Warganet \\
\hline 10 & sandi_mio & 2606452.077 & Politikus \\
\hline
\end{tabular}

Sumber: olahan data peneliti

Tabel 2 di atas menunjukkan tokoh kunci yang paling berpengaruh dalam jaringan \#2019GantiPresiden merupakan pengguna berlatarbelakang politikus dengan nilai betweeneess centrality sebesar 10350248.319. Secara mengejutkan, pengguna dengan profil warganet juga memiliki pengaruh dalam jaringan. Akun bernama @msapunya misalnya memiliki betweenness centrality sebesar 8851194.287 dan terpaut 1499054.032 poin dari akun @prabowo. Sementara itu apabila dibandingkan dengan politikus dan warganet, peran pengguna yang berlatarbelakang jurnalis tidak terlalu berpengaruh dalam jaringan \#2019GantiPresiden. Dari 10 (sepuluh) tokoh kunci yang paling berpengaruh, jurnalis menempati posisi ke-5. Tabel 2 di atas juga menunjukkan bahwa tokoh sentral dalam jaringan \# 2019GantiPresiden adalah pengguna dengan latar belakang politikus.

Sementara dalam jaringan \#2019TetapJokowi, pengguna dengan profil warganet tampak lebih dominan dibanding pengguna berlatarbelakang politikus. Tabel 3 di bawah ini menunjukkan dominasi warganet di mana 8 (delapan) dari 10 (sepuluh) tokoh kunci dalam jaringan \#2019TetapJokowi adalah mereka yang tidak masuk dalam kategori politikus maupun jurnalis. Selain warganet, tokoh yang berpengaruh dalam jaringan adalah politikus dengan nilai betweenness centrality sebesar 457188,8569. Menariknya, pengguna dengan latar belakang jurnalis sama sekali tidak muncul dalam daftar sepuluh besar tokoh sentral di jaringan \#2019TetapJokowi. 
Tabel 3. Sepuluh Besar Tokoh Kunci dalam Jaringan \#2019TetapJokowi

\begin{tabular}{clll}
\hline No & Nama Akun & Sentralitas Perantara & Kategori \\
\hline 1 & Jokowi & 457188.8569 & Politikus \\
\hline 2 & Addiems & 229982.9581 & Warganet \\
\hline 3 & je_latah & 129409.884 & Warganet \\
\hline 4 & hiphop74934648 & 41459.56554 & Warganet \\
\hline 5 & Ardhanamin & 40662 & Warganet \\
\hline 6 & sonnyprakosa7 & 23423.65599 & Warganet \\
\hline 7 & Hexagraph & 21273.51731 & Warganet \\
\hline 8 & 54triya_ & 19210.06791 & Warganet \\
\hline 9 & Rikadwilstr & 19207.28191 & Warganet \\
\hline 10 & Prabowo & 19003.7253 & Politikus \\
\hline
\end{tabular}

Sumber: olahan data peneliti

Meskipun berdasarkan Tabel 3 pengguna yang berlatarbelakang jurnalis tidak muncul sebagai tokoh kunci yang paling berpengaruh dalam jaringan \#2019TetapJokowi, tetapi mereka memengaruhi jumlah pesan yang dihasilkan dalam diskusi politik daring. Hal itu didukung oleh hasil penelitian lebih lanjut yang menemukan bahwa 10 akun paling aktif dalam memproduksi pesan Twitter baik dari jaringan \#2019GantiPresiden maupun \#2019TetapJokowi adalah institusi media (lihat Tabel 4).

Tabel 4. Top 10 Tweeter dalam Jaringan \# 2019TetapJokowi dan \# 2019GantiPresiden

\begin{tabular}{cll}
\hline No & Nama akun & Kategori \\
\hline 1 & Detikcom & Perusahaan media \\
\hline 2 & republikaonline & Perusahaan media \\
\hline 3 & metro_tv & Perusahaan media \\
\hline 4 & Vivacoid & Perusahaan media \\
\hline 5 & cakrawala_info & Perusahaan media \\
\hline 6 & Beritasatu & Perusahaan media \\
\hline 7 & Sindonews & Perusahaan media \\
\hline 8 & Kompastv & Perusahaan media \\
\hline 9 & liputan6dotcom & Perusahaan media \\
\hline 10 & okezonenews & Perusahaan media \\
\hline & Sumber: olahan data peneliti &
\end{tabular}

Struktur jejaring sosial suatu diskusi politik daring memiliki kecenderungan yang tinggi untuk terpolarisasi secara politik. Hal ini menegaskan apa yang disampaikan oleh Smith (2018) bahwa struktur jaringan polarized crowd cenderung terbentuk pada diskusi politik daring, 
sementara fragmented crowd cenderung terbentuk pada diskusi yang membicarakan tokoh publik seperti pesohor. Selain itu, jaringan diskusi politik daring juga berpeluang besar memunculkan homofili politik yang tinggi (Himelboim et al., 2016) serta memiliki kelompokkelompok kecil yang padat yang kurang memiliki keterhubungan dengan kelompok lain. Karakteristik tersebut terkonfirmasi oleh adanya kecenderungan para peserta diskusi politik daring untuk berinteraksi dengan peserta lain yang berpikiran sama daripada berinteraksi dengan peserta yang diasumsikan memiliki pandangan berbeda mengenai topik tertentu (Garrett \& Resnick, 2011; Al Zamal et al., 2012; Himelboim et al., 2013; Boutyline \& Willer, 2017). Klaim bahwa diskusi politik secara daring membentuk struktur jaringan yang terpolarisasi bukanlah sesuatu yang mengejutkan. Mengapa demikian? Karena tanpa platform komunikasi daring seperti Twitter pun, khalayak dapat terpolarisasi oleh pemberitaan media konvensional sebagaimana telah dibahas oleh Arceneaux et al. (2012).

Temuan studi ini menunjukkan sejumlah bukti yang menguatkan sekaligus juga menentang pandangan dominan bahwa diskusi politik daring cenderung terpolarisasi. Mengadopsi tipologi social media networks on Twitter yang dikemukakan oleh Smith (2018), studi ini menemukan bahwa struktur jaringan \#2019GantiPresiden secara konsisten terpolarisasi selama jangka waktu 30 hari. Dari analisis data juga diketahui bahwa peta jejaring sosial dari diskusi politik menggunakan tagar \#2019GantiPresiden memiliki dua karakteristik. Pertama, peta jejaring sosial tersebut terdiri dari dua atau lebih kelompok padat yang tidak memiliki koneksi satu sama lain. Kedua, peta jejaring sosial \#2019GantiPresiden memiliki sejumlah kecil 'isolates' sebagai hasil dari pembentukan kelompok dengan kepadatan tinggi. Dengan demikian temuan pertama menguatkan pandangan bahwa pengguna yang terlibat dalam diskusi daring terpolarisasi.

Sementara itu hasil analisis struktur jaringan \#2019TetapJokowi menunjukkan hal yang berbeda. Diskusi politik dengan tagar \#2019TetapJokowi membentuk jaringan brand cluster dengan polarisasi terbatas dan mayoritas pengguna dalam jaringan tersebut terisolasi. Hal itu dimungkinkan karena koneksi yang terjalin antarpengguna relatif sedikit mengingat aktivitas utama mereka adalah tweeting atau sekadar membuat satu pesan tertentu tanpa berinteraksi dengan pengguna lain menggunakan fitur reply, mention, atau retweet. Perbandingan aktivitas para pengguna Twitter yang terlibat dalam diskusi dengan menggunakan tagar \#2019TetapJokowi dan \# 2019GantiPresiden dapat dilihat pada Gambar 5 di bawah ini. 


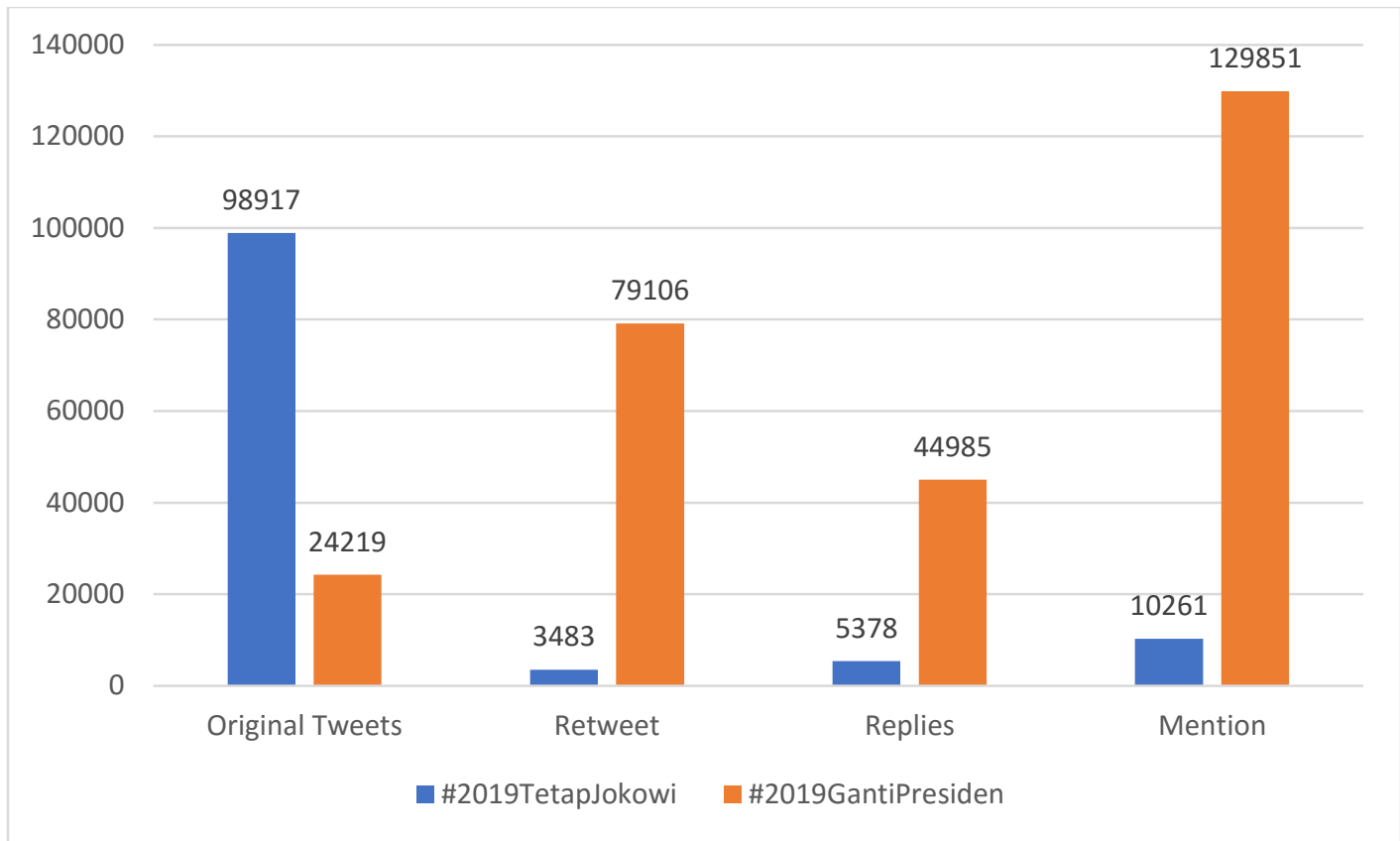

Gambar 5. Pesan Twitter dari Setiap Kata Kunci Berdasarkan Jenisnya Sumber: olahan data peneliti

Dalam jangka waktu 30 hari, jumlah cuitan (original tweet) yang dipublikasikan oleh pengguna tagar \#2019TetapJokowi relatif tinggi yakni sebanyak 98.917 tweet (lihat Gambar 5). Namun, angka retweet, reply, dan mention dalam jaringan ini masing-masing lebih kecil dibandingkan jaringan \#2019GantiPresiden. Padahal jumlah pesan asli pengguna \#2019GantiPresiden tidak sampai setengah dari jumlah pesan jaringan \#2019TetapJokowi yaitu sebanyak 24.219 original tweet. Dengan demikian dapat dikatakan bahwa sebagian besar pengguna Twitter yang terlibat dalam diskusi politik dengan menggunakan tagar \#2019TetapJokowi terisolasi.

Temuan tersebut dapat dijelaskan dengan mempertimbangkan konsep celebrity politician (politikus pesohor) yang dikemukakan oleh Street (2004). Street (2004) menyatakan bahwa seseorang dapat dikategorikan sebagai politikus pesohor ketika ia memiliki satu di antara dua karakteristik utama. Pertama, seorang politikus dapat dianggap sebagai politikus pesohor karena latar belakangnya yang berasal dari industri hiburan. Politikus pesohor jenis ini menggunakan latar belakang mereka untuk memperoleh panggung politik. Kedua, seseorang dapat dianggap sebagai politikus pesohor ketika ia berupaya menggunakan "beraneka bentuk dan asosiasi pesohor untuk meningkatkan citra dan menyebarluaskan pesan mereka" (Street, 2004, p. 437). Upaya-upaya itu misalnya tampak dari unggahan foto politikus dengan artis atau figur terkenal di media sosial.

Berdasarkan konsep tersebut, maka figur Joko Widodo dapat dianggap sebagai politikus pesohor karena ia memiliki karakteristik pertama maupun kedua. Joko Widodo bukanlah seseorang yang berasal dari industri hiburan, tetapi popularitasnya dapat menandingi para pesohor lain di Indonesia. Selama periode pertama pemerintahannya dari 2014 hingga 2019, Joko Widodo sering tampil di media massa maupun media sosial. la juga berulang kali mengunggah foto dirinya bersama tokoh-tokoh dunia maupun dengan para pesohor nasional. 
Gambar 6 di bawah ini menunjukkan beberapa contoh pesan yang diunggah oleh Joko Widodo di akun media sosialnya.
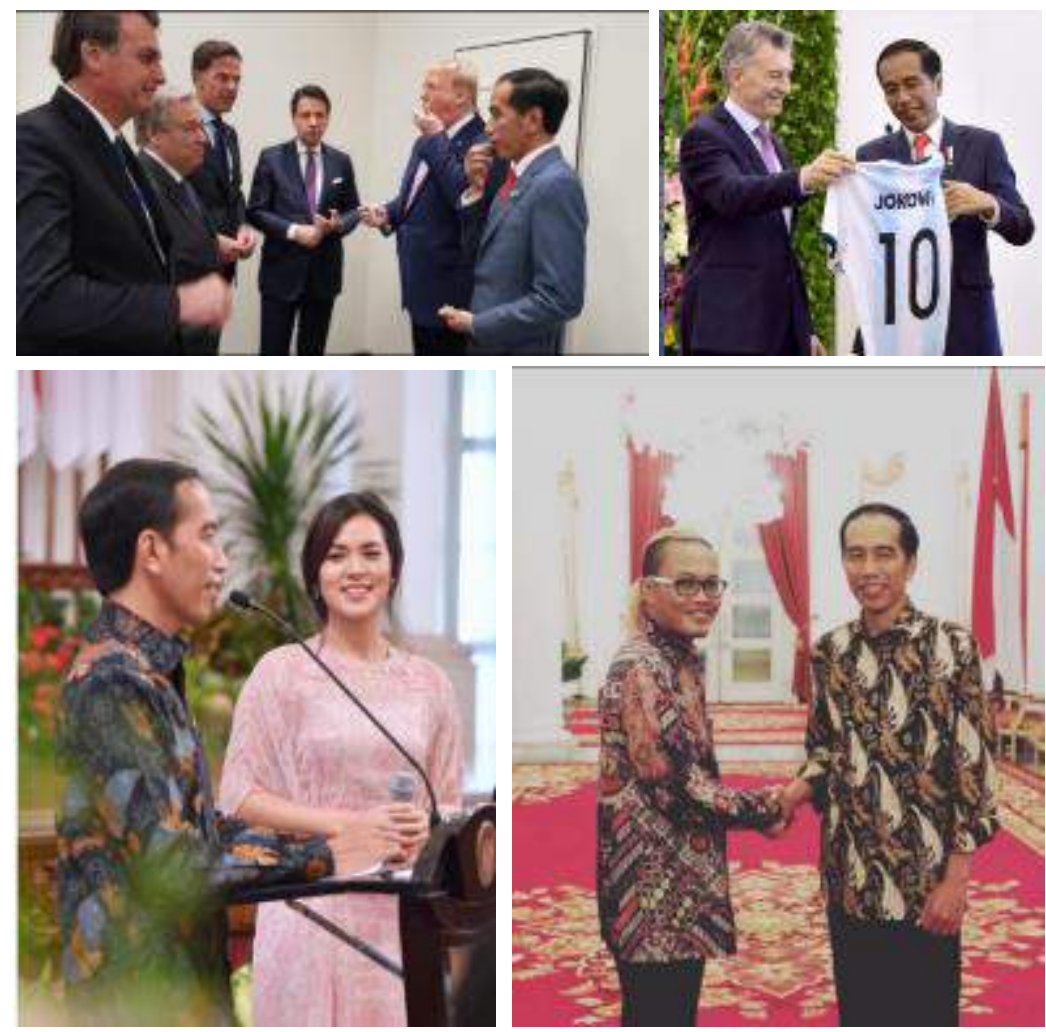

Gambar 6. Joko Widodo Berfoto Bersama Tokoh Dunia dan Pesohor Tanah Air Sumber: Postingan Instagram Presiden Jokowi (@jokowi)

Gambar 6 di atas menunjukkan kebersamaan Joko Widodo dengan beberapa figur baik dari kalangan pesohor Indonesia maupun tokoh-tokoh dunia. Dengan menampilkan kebersamaan itu di media sosial, Joko Widodo membangun citranya sebagai politikus pesohor. Hal ini juga menjelaskan mengapa struktur jaringan \#JokowiTetapPresiden diidentifikasi sebagai brand cluster atau terfragmentasi yang dibentuk oleh para pendukungnya di Twitter.

Studi ini menunjukkan bahwa struktur jaringan yang terbentuk oleh diskusi politik daring tidak selalu terpolarisasi sebagaimana dibahas oleh banyak literer. Hal ini dimungkinkan karena munculnya faktor lain seperti karakteristik politikus dan figur mereka yang diasosiasikan sebagai pesohor atau merek (brand) yang memengaruhi jenis kerumunan (jaringan) yang terbentuk.

\section{KESIMPULAN}

Analisis pada jaringan \#2019TetapJokowi membuktikan bahwa diskusi politik daring tidak selalu terpolarisasi dalam hal jejaring sosial. Berbeda dengan \#2019TetapJokowi, jaringan sosial \#2019GantiPresiden secara politik terpolarisasi. Perbedaan pola jaringan tersebut dimungkinkan oleh ketokohan Joko Widodo yang dianggap sebagai sebuah brand atau politikus pesohor. Sehingga kerumunan yang terbentuk oleh para pengguna tagar \#2019TetapJokowi 
merupakan sebuah brand community. Penelitian lebih lanjut tentu perlu dilakukan untuk mengeksplorasi temuan ini secara lebih rinci.

Temuan dari hasil studi ini memberi wawasan baru mengenai dampak penggunaan media sosial khususnya Twitter, terhadap proses komunikasi politik yang terjadi pada negara demokrasi di luar Amerika Serikat. Studi ini juga menjadi salah satu upaya awal bagi studi lanjutan mengenai diskusi politik daring di Indonesia dengan menggunakan lebih dari satu tagar sebagai kata kunci dalam pengumpulan data. Berbeda dengan penelitian terdahulu yang menggunakan kata kunci tunggal, seperti \#ausvotes untuk menganalisis diskusi politik di Australia (Bruns \& Burgess, 2011), penggunaan dua kata kunci dalam studi ini memberi pemahaman yang berbeda dalam analisis jejaring sosial sehingga berkontribusi terhadap pengembangan metodologi penelitian jejaring sosial.

Studi ini memiliki keterbatasan terkait waktu dan perbandingan data. Singkatnya durasi pengumpulan data yang hanya dilakukan selama 30 hari sementara durasi debat politik tentang Pilpres telah terjadi selama beberapa bulan sebelum hari pemungutan suara. Studi dengan durasi waktu yang lebih lama dapat menambah cakupan dan pemahaman yang lebih baik tentang keseluruhan pola debat politik. Perbandingan data dengan negara lain juga dapat menghasilkan wawasan yang lebih baik untuk mengetahui kesamaan dan perbedaan diskusi politik daring di Indonesia dengan negara lain.

\section{DAFTAR PUSTAKA}

Al Zamal, F., Liu, W., \& Ruths, D. (2012). Homophily and Latent Attribute Inference: Inferring Latent Attributes of Twitter Users from Neighbors. ICWSM, 270(2012).

Arceneaux, K., Martin, J., \& Chad, M. (2012). Polarized Political Communication, Oppositional Media Hostility, and Selective Exposure. The Journal of Politics, 74(1), 174. JSTOR Journals.

Beaufort, M. (2018). Digital media, political polarization and challenges to democracy. 7, 915. British Library Document Supply Centre Inside Serials \& Conference Proceedings.

Bennet, W. L. (2003). Lifestyle Politics and Citizen-Consumers: Identity, Communication and Political Action in Late Modern Society. In J. Corner \& D. Pels (Eds.), Media and the restyling of politics: Consumerism, celebrity and cynicism. (UniM INTERNET resource; pp. 137-150). SAGE.

Boutyline, A., \& Willer, R. (2017). The Social Structure of Political Echo Chambers: Variation in Ideological Homophily in Online Networks. Political Psychology, 38(3), 551-569. Business Source Complete.

Boynton, G. R., Daniels, K., Dawkins, M., Kopish, J., Makar, M., McDavid, W., Murphy, M., Osmundson, J., Steenblock, T., Sudarmawan, A., Wiese, P., Zora, A., \& Cook, J. (2014). The Political Domain Goes to Twitter: Hashtags, Retweets and URLs. Open Journal of Political Science, 8-15. Airiti Library eBooks \& Journals.

Bruns, A., \& Burgess, J. (2011). \#Ausvotes: How Twitter Covered the 2010 Australian Federal Election. Communication, Politics \& Culture, 44(2), 37-56. Australian Public Affairs - Full Text.

Garrett, R. K., \& Resnick, P. (2011). Resisting Political Fragmentation on the Internet. Daedalus, 140(4), 108. JSTOR Journals.

Hansen, Shneideran, dan Smith (2012). Analyising Social Media Networks with NodeXL: Insight from a connected world. Morgan Kaufman.

Himelboim, I., McCreery, S., \& Smith, M. (2013). Birds of a Feather Tweet Together: Integrating Network and Content Analyses to Examine Cross-Ideology Exposure on Twitter. JOURNAL OF COMPUTERMEDIATED COMMUNICATION, 18(2), 154-174. EDSWSS. 
Himelboim, I., Sweetser, K. D., Tinkham, S. F., Cameron, K., Danelo, M., \& West, K. (2016). Valence-Based Homophily on Twitter: Network Analysis of Emotions and Political Talk in the 2012 Presidential Election. New Media \& Society, 18(7), 1382-1400. MLA International Bibliography.

Kadry, S., \& Al-Taie, M. Z. (2014). Social network analysis: An introduction with an extensive implementation to a large-scale online network using Pajek. (UniM INTERNET resource). Bentham Science Publishers.

Lee, H., \& Hahn, K. S. (2018). Partisan selective following on Twitter over time: Polarization or depolarization? Asian Journal of Communication, 28(3), 227-246. Bibliography of Asian Studies.

Lilleker, D. G., Jackson, N., \& Koc-Michalska, K. (2016). Social Media in the UK Election Campaigns 20082014. In A. Bruns, G. Enli, E. Skogerbo, A. O. Larsson, \& C. Christensen (Eds.), The Routledge companion to social media and politics. (UniM INTERNET resource; pp. 325-337). Routledge.

Mutz, D. C. (2006). Hearing the other side: Deliberative versus participatory democracy. (UniM Bail 306.2 MUTZ). Cambridge University Press.

Skovsgaard, M., \& van Dalen, A. (2016). Not Just a Face(book) in the Crowd Candidates' Use of Facebook during the Danish 2011 Parliamentary Election Campaign. In A. Bruns, G. Enli, E. Skogerbo, A. O. Larsson, \& C. Christensen (Eds.), The Routledge companion to social media and politics. (UniM INTERNET resource; pp. 351-363). Routledge.

Smith, M. A. (2018). NodeXL: Simple Network Analysis for Social Media. In R. Alhajj \& J. Rokne (Eds.), Encyclopedia of social network analysis and mining (UniM INTERNET resource; Second edition., pp. 1617-1633). Springer.

Street, J. (2004). Celebrity Politicians: Popular Culture and Political Representation. British Journal of Politics \& International Relations, 6(4), 435-452. SocINDEX with Full Text.

Sunstein, C. R. (2009). Republic.com 2.0. Princeton University Press; Books at JSTOR.

Wakita, K., \& Tsurumi, T. (2007, May). Finding community structure in mega-scale social networks. In Proceedings of the 16th international conference on World Wide Web (pp. 1275-1276).

Wojcieszak, M. E., \& Mutz, D. C. (2009). Online Groups and Political Discourse: Do Online Discussion Spaces Facilitate Exposure to Political Disagreement? Journal of Communication, 59(1), 40-56. Communication \& Mass Media Complete.

Wright, S., Graham, T., \& Jackson, D. (2016). Third Space, Social Media, and Everyday Political Talk. In A. Bruns, G. Enli, E. Skogerbo, A. O. Larsson, \& C. Christensen (Eds.), The Routledge companion to social media and politics. (UniM INTERNET resource; pp. 74-88). Routledge. 